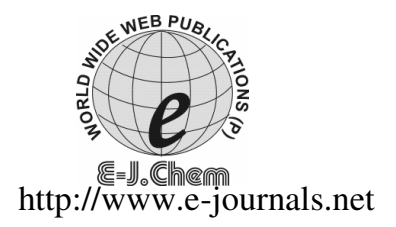

ISSN: 0973-4945; CODEN ECJHAO

E-Journal of Chemistry

2011, 8(2), 903-909

\title{
Kinetics and Mechanism of Oxidation of Diethanolamine and Triethanolamine by Potassium Ferrate
}

\author{
SHAN JINHUAN* and ZHANG JIYING \\ College of Chemistry and Environmental Science \\ Hebei University, Baoding 071002, China \\ shanjinhuaner@yahoo.com.cn
}

Received 18 May 2010; Accepted 23 July 2010

\begin{abstract}
The kinetics of oxidation of diethanolamine and triethanolamine by potassium ferrate $(\mathrm{VI})$ in alkaline liquids at a constant ionic strength has been studied spectrophotometrically in the temperature range of $278.2 \mathrm{~K}-293.2 \mathrm{~K}$. The reaction shows first order dependence on potassium ferrate(VI), first order dependence on each reductant, The observed rate constant $\left(k_{\mathrm{obs}}\right)$ decreases with the increase in $\left[\mathrm{OH}^{-}\right]$, the reaction is negative fraction order with respect to $\left[\mathrm{OH}^{-}\right]$. A plausible mechanism is proposed and the rate equations derived from the mechanism can explain all the experimental results. The rate constants of the ratedetermining step and the thermodynamic activation parameters are calculated.
\end{abstract}

Keywords: Diethanolamine, Triethanolamine, Potassium ferrate, Kinetics and mechanism, Oxidation

\section{Introduction}

Potassium ferrate is a powerful oxidizing agent in the whole $\mathrm{pH}$ range, it is widely used as a water treatment agent ${ }^{1-3}$ in 1970s. It can remove the phenolic, sulfide and other organic pollutants ${ }^{4-6}$ which are residual in wastewater and also can oxidize the cyanide into $\mathrm{NO}_{2}{ }^{-}$, $\mathrm{NO}_{3}{ }^{-}$and $\mathrm{HCO}_{3}{ }^{-}$which are harmless to environment ${ }^{7-10}$. Ferrate as a very effective, selective oxidant which can remove effectively $\mathrm{H}_{2} \mathrm{~S}, \mathrm{CH}_{3} \mathrm{SH}_{2}$ and $\mathrm{NH}_{3}$ etc ${ }^{11}$ odor substances in biological sludge. The treated sludge can be used as chemical fertilizer and soil conditioner, it is propitious to waste resource utilization.

Applied prospects of ferrate oxidation are becoming hotspot of research ${ }^{12}$. Oxidability of ferrate is stronger than potassium permanganate, ozone and chlorine. As a new water treatment agent, it has a trend to replace chlorine-atom. In recent years, James Carr etc. used potassium ferrate as water treatment agent, while they studied self-decomposition of potassium ferrate in a wide $\mathrm{pH}$ range $(\mathrm{pH}=2.53-9.31)^{13}$ and the reaction of oxidizing a variety of organic matters ${ }^{14}$. They had proposed rate equation which is applicable to the majority systems. The rate equation includes self-decomposition of potassium ferrate and the 
reaction of potassium ferrate with the substrate. They also established new methods to deal with kinetic data of such reaction systems ${ }^{15}$. However, all studies were not put forward the reaction mechanism to explain the experimental facts.

Diethanolamine and triethanolamine have a very wide range of uses, they can be directly used as surfactants for detergents and cleaning agent formulations; they also can be used for gas purification agent to remove carbon dioxide or hydrogen sulfide gas. In addition,diethanolamine is raw materials to synthesize drugs and it is also a cross linking agent for production of high resilience polyurethane foam. Triethanolamine is also used as preservatives, water repellent, analytical reagent and $\mathrm{PH}$ value regulators. In this paper, the kinetics and mechanism of oxidation of diethanolamine and triethanolamine by potassium ferrate were studied in detail.

\section{Experimental}

All the reagents used were of A.R. grade. All solutions were prepared with doubly distilled water. Potassium ferrate $\left(\mathrm{K}_{2} \mathrm{FeO}_{4}\right)$ was prepared by the method of Thompson et $a l^{15}$. The concentration of $\mathrm{K}_{2} \mathrm{FeO}_{4}$ was derived from its absorption at $507 \mathrm{~nm}(\varepsilon=$ $1.15 \times 10^{3} \mathrm{~L} \cdot \mathrm{mol}^{-1} \cdot \mathrm{cm}^{-1}$ ). The solution of $\mathrm{K}_{2} \mathrm{FeO}_{4}$ was always freshly prepared before use. $\mathrm{KNO}_{3}$ and the $\mathrm{Na}_{2} \mathrm{HPO}_{4}$ buffer solution were used to maintain ionic strength and acidity of the reaction, respectively. Measurements of the kinetics were performed using a TU-1900 spectrophotometer (Beijing, China) fitted with a DC-2010 thermostat $( \pm 0.1 \mathrm{~K}$, Baoding, China).

\section{Kinetics measurements}

All kinetics measurements were carried out under pseudo-first order conditions. The oxidant and reductant were dissolved in buffer solution which contained required concentration of $\mathrm{KNO}_{3}$ and $\mathrm{Na}_{2} \mathrm{HPO}_{4}$. The reaction was initiated by mixing the $\mathrm{Fe}(\mathrm{VI})$ to reductant solution The reaction process was monitored automatically by recording the concentration decrease of all the $\mathrm{Fe}(\mathrm{VI})$ species with time $(t)$ at $507 \mathrm{~nm}$ with a TU-1900 spectrophotometer. All other species did not absorb significantly at this wavelength.

\section{Product analysis}

After completion of the reaction, adding $\mathrm{K}_{3} \mathrm{Fe}(\mathrm{CN})_{6}$ to the solution have non-experimental phenomena, while adding $\mathrm{K}_{4} \mathrm{Fe}(\mathrm{CN})_{6}$ prussian blue precipitate was generated; by adding 2,2-bipyridyl methanol solution have non- experimental phenomena also. It proves that the final reduction product of $\mathrm{Fe}(\mathrm{VI})$ is $\mathrm{Fe}(\mathrm{III})^{16}$. After completion of the reaction, the oxidation product was identified as aldehyde which was precipitated as 2, 4-dinitrophenylhy drazone derivative.

\section{Reaction intermediate}

1,10-Phenanthroline was added to the reductant solution, then it was mixed with $\mathrm{K}_{2} \mathrm{FeO}_{4}$ solution, purple disappears and at the same time orange appears, which indicates that $\mathrm{Fe}$ (phen) ${ }_{3}{ }^{2-}$ has generated in the process of the reaction ${ }^{16}$. It proves that $\mathrm{Fe}(\mathrm{II})$ has once appeared in the reduction process of $\mathrm{Fe}(\mathrm{VI})$ to $\mathrm{Fe}(\mathrm{III})$.

\section{Results and Discussion}

\section{Evaluation of pseudo-first order rate constants}

Under the conditions of [reductant $]_{0} \gg>[\mathrm{Fe}(\mathrm{VI})]_{0}$, the plots of $\ln \left(A_{\mathrm{t}}-A_{\infty}\right)$ versus time $t$ gives straight lines, details of the evaluation were described in our previous work ${ }^{17}$. 


\section{Rate dependence on [reductant]}

At fixed $[\mathrm{Fe}(\mathrm{VI})],\left[\mathrm{OH}^{-}\right]$, ionic strength $I$, the values of $k_{\mathrm{obs}}$ were determined at different temperatures. The $k_{\mathrm{obs}}$ were found to be increased with the increase of reactant concentration. The plots of $k_{\mathrm{obs}}$ versus [reductant] were linear. For the plots passed through the grid origin (Figure 1 and Figure 2), the reaction was first order with reductant.

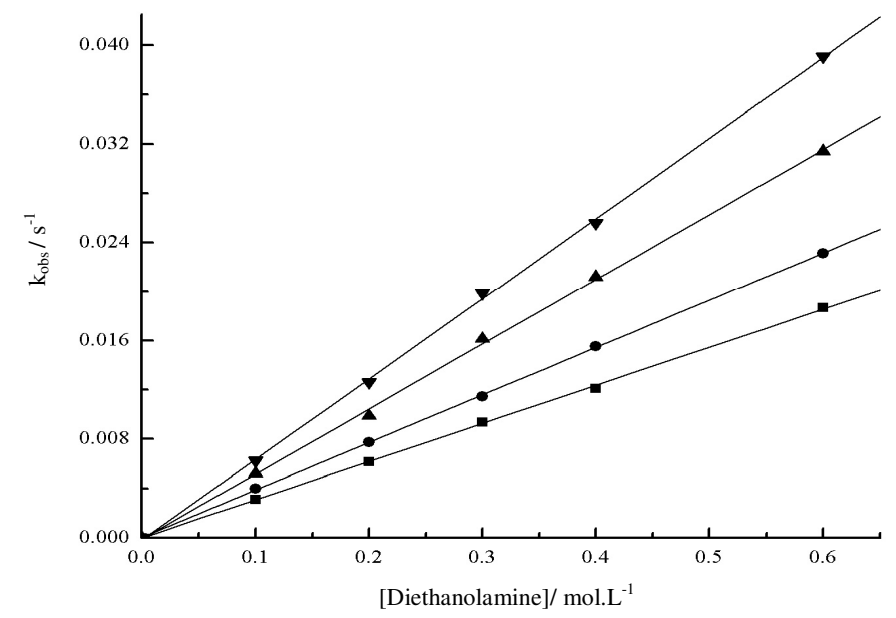

Figure 1. Plots of $k_{\mathrm{obs}}$ versus [Diethanolamine] at different temperatures(r $\left.\geq 0.999\right),[\mathrm{Fe}(\mathrm{VI})]$ $=1.03 \times 10^{-4} \mathrm{~mol} \cdot \mathrm{L}^{-1},\left[\mathrm{OH}^{-}\right]=6.76 \times 10^{-5} \mathrm{~mol} \cdot \mathrm{L}^{-1}, I=1.00 \mathrm{~mol} \cdot \mathrm{L}^{-1}$

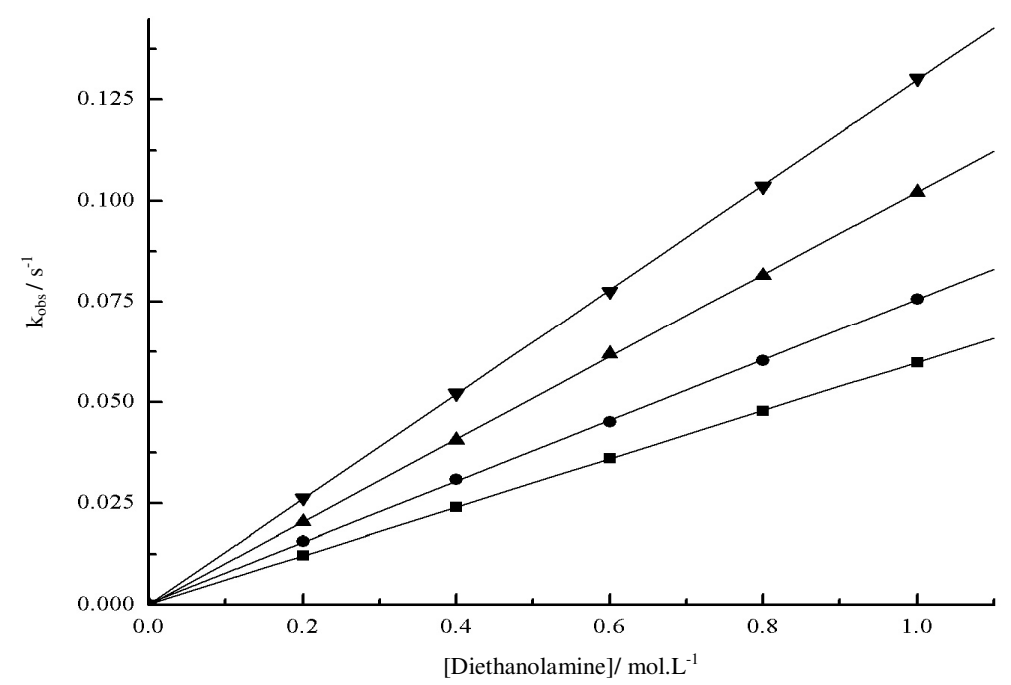

Figure 2. Plots of $k_{\mathrm{obs}}$ versus [Triethanolamine] at different temperatures( $\left.\mathrm{r} \geq 0.999\right)$, $[\mathrm{Fe}(\mathrm{VI})]=1.11 \times 10^{-4} \mathrm{~mol} \cdot \mathrm{L}^{-1},\left[\mathrm{OH}^{-}\right]=1.38 \times 10^{-4} \mathrm{~mol} \cdot \mathrm{L}^{-1}, I=1.00 \mathrm{~mol} \cdot \mathrm{L}^{-1}$

Rate dependence on $\left[\mathrm{OH}^{-}\right]$

Under fixed [Fe(VI)], [reductant], ionic strength $I$ and temperature, $k_{\mathrm{obs}}$ values were decreased with an increase of $\left[\mathrm{OH}^{-}\right]$, The order with respect to $\mathrm{OH}^{-}$was found to be negative fractional. The plots of $1 / \mathrm{k}_{\mathrm{obs}}$ versus $[\mathrm{OH}-]$ were liners (Figure $3 \& 4$ ). 


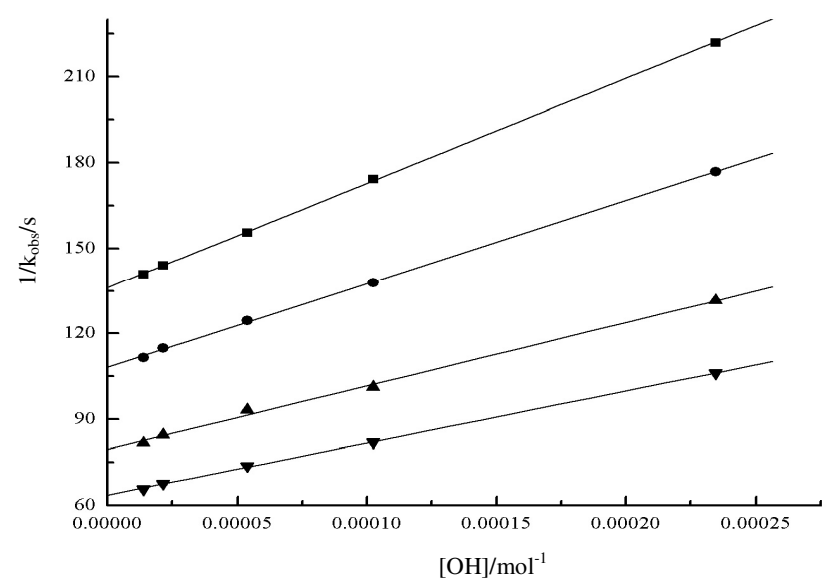

Figure 3. Plots of $1 / k_{\mathrm{obs}}$ versus $\left[\mathrm{OH}^{-}\right]$at different temperatures $(\mathrm{r} \geq 0.998)[\mathrm{Fe}(\mathrm{VI})]=$ $1.01 \times 10^{-4} \mathrm{~mol} \cdot \mathrm{L}^{-1}$, [Diethanolamine $]=0.20 \mathrm{~mol} \cdot \mathrm{L}^{-1}, I=1.00 \mathrm{~mol} \cdot \mathrm{L}^{-1}$

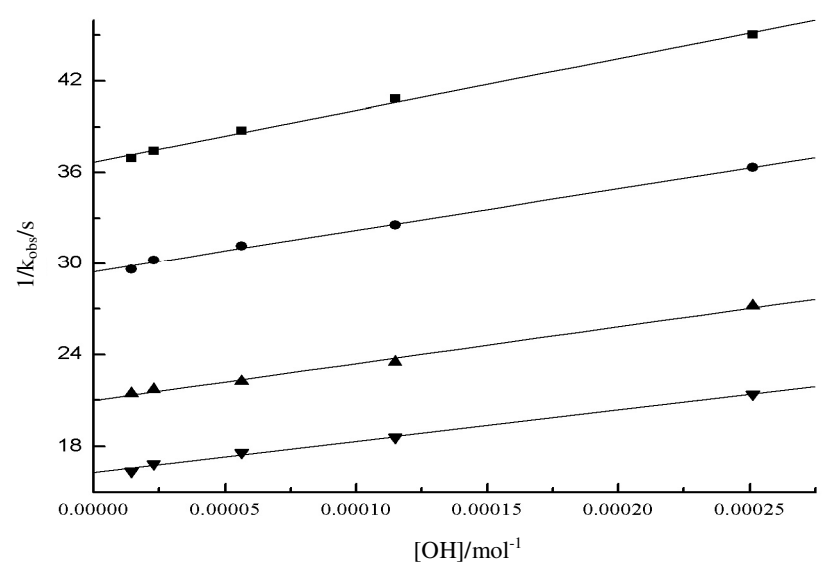

Figure 4. Plots of $1 / k_{\mathrm{obs}}$ versus $\left[\mathrm{OH}^{-}\right]$at different temperatures $(\mathrm{r} \geq 0.997)[\mathrm{Fe}(\mathrm{VI})]=$ $1.04 \times 10^{-4} \mathrm{~mol} \cdot \mathrm{L}^{-1}$, [Triethanolamine $]=0.40 \mathrm{~mol} \cdot \mathrm{L}^{-1}, I=1.00 \mathrm{~mol} \cdot \mathrm{L}^{-1}$

\section{Reaction mechanism}

James Carr ${ }^{14}$ has given the rate equation as follows rate $=\mathrm{k}_{1}\left[\mathrm{FeO}_{4}{ }^{2-}\right]+\mathrm{k}_{2}\left[\mathrm{FeO}_{4}{ }^{2-}\right]^{2}+\mathrm{k}\left[\mathrm{FeO}_{4}{ }^{2-}\right][\mathrm{S}]$ where [S] represents substrate concentration. According to James Carr ${ }^{14}$, the first two terms are contribution of $\mathrm{K}_{2} \mathrm{FeO}_{4}$ self-decomposition rate to the reaction system when there is no substrate. In this article, under the experimental conditions, the self-decomposition rate of $\mathrm{K}_{2} \mathrm{FeO}_{4}$ is far less than oxidation rate of reductant reaction, so we get the rate equation: rate $=\mathrm{k}\left[\mathrm{FeO}_{4}{ }^{2-}\right][\mathrm{R}]$. In essence, the results were consistent with James ${ }^{13}$ findings Ferrate(VI) is a dicarboxylic acid, where:

$$
\begin{aligned}
& \mathrm{H}_{2} \mathrm{FeO}_{4} \rightleftharpoons \mathrm{HFeO}_{4}^{-}+\mathrm{H}^{+} \quad \mathrm{pK}_{\mathrm{al}}=3.5 \\
& \mathrm{HFeO}_{4}{ }^{-} \rightleftharpoons \mathrm{H}^{+}+\mathrm{FeO}_{4}{ }^{2-} \quad \mathrm{pK}_{\mathrm{a} 2}=7.8
\end{aligned}
$$

Under the experimental conditions of this paper, $\mathrm{FeO}_{4}{ }^{2-}$ will be partial hydrolysis:

$$
\mathrm{FeO}_{4}{ }^{2-}+\mathrm{H}_{2} \mathrm{O} \rightleftharpoons \mathrm{HFeO}_{4}{ }^{-}+\mathrm{OH}^{-}
$$




$$
\text { Hence: } K_{h}=\frac{\left[\mathrm{HFeO}_{4}^{-}\right]\left[\mathrm{OH}^{-}\right]}{\left[\mathrm{FeO}_{4}{ }^{2-}\right]}=\frac{K_{w}}{K_{a 2}}=6.31 \times 10^{-7}
$$

This experiment was performed at $\mathrm{pH}=9.83$ and 10.14 , then there is

$$
\frac{\left[\mathrm{HFeO}_{4}^{-}\right]}{\left[\mathrm{FeO}_{4}{ }^{2-}\right]}=\frac{K_{h}}{\left[\mathrm{OH}^{-}\right]}=9.33 \times 10^{-3} \text { and } \frac{\left[\mathrm{HFeO}_{4}^{-}\right]}{\left[\mathrm{FeO}_{4}{ }^{2-}\right]}=\frac{K_{h}}{\left[\mathrm{OH}^{-}\right]}=4.57 \times 10^{-3}
$$

Obviously, $\mathrm{HFeO}_{4}^{-}$both have a small percentage in the system. The concentration of $\mathrm{HFeO}_{4}^{-}$is small, but it is very easy to form complex with reductant in the presence of hydrogen atom and the complex has higher activity. Under the attack of hydroxyl, the complex dissociates into $\mathrm{Fe}(\mathrm{IV})$ and product, then $\mathrm{Fe}(\mathrm{IV})$ with another molecule of reductant further react to generate $\mathrm{Fe}(\mathrm{II})$ and product. Therefore, reaction is mainly through $\mathrm{HFeO}_{4}^{-}$to realize. According to discussion, the following reaction mechanism is proposed:

$$
\begin{gathered}
\mathrm{FeO}_{4}{ }^{2-}+\mathrm{H}_{2} \mathrm{O} \stackrel{K_{\mathrm{h}}}{\rightleftharpoons} \mathrm{HFeO}_{4}{ }^{-}+\mathrm{OH}^{-} \\
\mathrm{HFeO}_{4}{ }^{-}+\mathrm{R} \stackrel{k_{2}}{\underset{k_{-2}}{\rightleftharpoons}} \mathrm{X} \\
\mathrm{X}+\mathrm{OH}^{-} \stackrel{k_{3}}{\longrightarrow} \mathrm{Fe}(\mathrm{IV})+\mathrm{P} \text { (Product) } \\
\mathrm{Fe}(\mathrm{IV})+\mathrm{R} \stackrel{k_{4}}{\longrightarrow} \mathrm{Fe}(\mathrm{II})+\mathrm{P} \text { (Product) } \\
\mathrm{Fe}(\mathrm{IV})+\mathrm{Fe}(\mathrm{II}) \stackrel{k_{5}}{\longrightarrow} 2 \mathrm{Fe}(\mathrm{III})
\end{gathered}
$$

Equation (4) is the rate-determining step, where R stands for reductant. As the rate of the disappearance of $\left[\mathrm{FeO}_{4}{ }^{2-}\right]$ was monitored, the rate of the reaction can be derived as

$$
-\frac{\mathrm{d}\left[\mathrm{FeO}_{4}{ }^{2-}\right]}{\mathrm{dt}}=k_{2}\left[\mathrm{HFeO}_{4}^{-}\right][\mathrm{R}]-k_{-2}[\mathrm{X}]=\frac{k_{2} k_{3}\left[\mathrm{HFeO}_{4}^{-}\right][\mathrm{R}]\left[\mathrm{OH}^{-}\right]}{k_{-2}+k_{3}\left[\mathrm{OH}^{-}\right]}
$$

Equation (9) can be obtained from (3): $\left[\mathrm{HFeO}_{4}{ }^{-}\right]=\frac{K_{\mathrm{h}}\left[\mathrm{FeO}_{4}{ }^{2-}\right]}{\left[\mathrm{OH}^{-}\right]}$

Substituting equation (9) into (8), we can get the following equation (10):

$$
\begin{gathered}
-\frac{\mathrm{d}\left[\mathrm{FeO}_{4}{ }^{2-}\right]}{\mathrm{dt}}=\frac{k_{2} k_{3} K_{\mathrm{h}}\left[\mathrm{FeO}_{4}{ }^{2-}\right][\mathrm{R}]}{k_{-2}+k_{3}\left[\mathrm{OH}^{-}\right]}=\frac{k_{2} k_{3} K_{\mathrm{h}}[\mathrm{R}]}{k_{-2}+k_{3}\left[\mathrm{OH}^{-}\right]}\left[\mathrm{FeO}_{4}{ }^{2-}\right] \\
k_{\text {obs }}=\frac{k_{2} k_{3} K_{\mathrm{h}}[\mathrm{R}]}{k_{-2}+k_{3}\left[\mathrm{OH}^{-}\right]}=\frac{k_{2} k^{\prime} K_{\mathrm{h}}[\mathrm{R}]}{1+k^{\prime}\left[\mathrm{OH}^{-}\right]}
\end{gathered}
$$

in the equation $k^{\prime}=k_{3} / k_{-2}$

$$
\frac{1}{k_{\mathrm{obs}}}=\frac{1+k^{\prime}\left[\mathrm{OH}^{-}\right]}{k_{2} k^{\prime} K_{\mathrm{h}}[\mathrm{R}]}=\frac{1}{k_{2} k^{\prime} K_{\mathrm{h}}[\mathrm{R}]}+\frac{\left[\mathrm{OH}^{-}\right]}{k_{2} K_{\mathrm{h}}[\mathrm{R}]}
$$

Equation (10) suggests that the reaction should be first order with respect to $\mathrm{Fe}(\mathrm{VI})$; equation (11) suggests that the order with respect to $\mathrm{R}$ is unity. The plot of $1 / k_{\mathrm{obs}}$ versus $\left[\mathrm{OH}^{-}\right]$derived from equation (12) at constant $[\mathrm{R}]$ is linear with positive intercept. These are consistent with the experimental phenomena. 
Meanwhile, the plots of $1 / k_{\mathrm{obs}}$ versus $\left[\mathrm{OH}^{-}\right]$were liner at different temperatures. From their slopes and equation (12), the rate-determining step constants $\left(k_{2}\right)$ were evaluated and the thermodynamic activation parameters date were obtained (Table 1$)^{18}$.

Table 1. Rate constants $\left(k_{2}\right)$ and Thermodynamic activation parameters of the ratedetermining step $(\mathrm{T}=298.2 \mathrm{~K})$

\begin{tabular}{|c|c|c|c|c|c|}
\hline \multicolumn{2}{|c|}{$\mathrm{T}, \mathrm{K} \rightarrow$} & 278.2 & 283.2 & 288.2 & 293.2 \\
\hline \multirow{2}{*}{$k_{2} / \mathrm{mol}^{-1} \cdot \mathrm{L} \cdot \mathrm{s}^{-1}$} & Diethanolamine & 21.61 & 26.68 & 35.78 & 43.57 \\
\hline & Triethanolamine & 116.70 & 144.34 & 163.90 & 193.90 \\
\hline Thermodynamic & Diethanolamine & \multirow{2}{*}{\multicolumn{4}{|c|}{$\begin{array}{l}E_{\mathrm{a}}=32.51 \mathrm{~kJ} \cdot \mathrm{mol}^{-1}, \Delta H^{\neq}=30.04 \mathrm{~kJ} \cdot \mathrm{mol}^{-1} \\
\Delta S^{\neq}=-110.94 \mathrm{~J} \cdot \mathrm{K}^{-1} \cdot \mathrm{mol}^{-1} \\
E_{\mathrm{a}}=22.40 \mathrm{~kJ} \cdot \mathrm{mol}^{-1}, \Delta H^{\neq}=19.92 \mathrm{~kJ} \cdot \mathrm{mol}^{-1} \\
\Delta S^{\neq}=-133.06 \mathrm{~J} \cdot \mathrm{K}^{-1} \cdot \mathrm{mol}^{-1}\end{array}$}} \\
\hline $\begin{array}{l}\text { activation } \\
\text { parameters }\end{array}$ & Triethanolamine & & & & \\
\hline
\end{tabular}

The plots of $\ln k$ vs. 1/T have following intercept (a) slope (b) and relative coefficient (r). Diethanolamine: $\mathrm{a}=17.12 \mathrm{~b}=-3910.59 \mathrm{r}=0.997$, Triethanolamine: $\mathrm{a}=14.46 \mathrm{~b}=-$ 2694.32; $\mathrm{r}=0.996$

It is noteworthy that according to equation (12) and Figure $3 \& 4$, we can get the values of $k^{\prime}$ under corresponding temperature and then, substituting the $k^{\prime}, k_{2}$ and $\left[\mathrm{OH}^{-}\right]$into equation (11), we can calculate the rate constants in corresponding $[R]$, we found that the calculated value is very close to the experimental value (Table 2 and Table 3). This also illustrates the equation (12) is correct and the reaction mechanism we supposed is reasonable.

Table 2. The values of $k_{\mathrm{obs}}$ experimental and calculated at different temperatures $\left(\left[\mathrm{OH}^{-}\right]\right.$ $=6.76 \times 10^{-5} \mathrm{~mol} \cdot \mathrm{L}^{-1} \mathrm{R}=$ diethanolamine)

\begin{tabular}{ccccccccccc}
\hline \multicolumn{2}{c}{ Conc.,mol. $\mathrm{L}^{-1}$} & $\rightarrow$ & 0.10 & \multicolumn{2}{c}{0.20} & \multicolumn{2}{c}{0.30} & \multicolumn{2}{c}{0.40} & \multicolumn{2}{c}{0.60} \\
\hline $\mathrm{T}, \mathrm{K}$ & $\operatorname{Exp}$ & $\mathrm{Cal}$ & $\operatorname{Exp}$ & $\mathrm{Cal}$ & $\operatorname{Exp}$ & $\mathrm{Cal}$ & $\operatorname{Exp}$ & $\mathrm{Cal}$ & Exp & $\mathrm{Cal}$ \\
\hline 278.2 & 0.00311 & 0.00311 & 0.00616 & 0.00622 & 0.00936 & 0.00932 & 0.0121 & 0.0124 & 0.0187 & 0.0186 \\
283.2 & 0.00398 & 0.00390 & 0.00772 & 0.00779 & 0.0114 & 0.0117 & 0.0155 & 0.0156 & 0.0232 & 0.0234 \\
288.2 & 0.00520 & 0.00529 & 0.00987 & 0.0106 & 0.0161 & 0.0159 & 0.0212 & 0.0212 & 0.0314 & 0.0317 \\
293.2 & 0.00623 & 0.00659 & 0.0126 & 0.0132 & 0.0199 & 0.0198 & 0.0256 & 0.0264 & 0.0391 & 0.0396 \\
\hline
\end{tabular}

Table 3. The values of $k_{\mathrm{obs}}$ experimental and calculated at different temperatures $\left(\left[\mathrm{OH}^{-}\right]\right.$ $=1.38 \times 10^{-4} \mathrm{~mol} \cdot \mathrm{L}^{-1} \mathrm{R}=$ triethanolamine)

\begin{tabular}{ccccccccccc}
\hline Conc.,mol. $\mathrm{L}^{-1}$ & \multicolumn{1}{c}{0.20} & \multicolumn{2}{c}{0.40} & \multicolumn{2}{c}{0.60} & \multicolumn{2}{c}{0.80} & \multicolumn{2}{c}{1.00} \\
\hline $\mathrm{T}, \mathrm{K}$ & Exp & Cal & Exp & Cal & Exp & Cal & Exp & Cal & Exp & Cal \\
\hline 278.2 & 0.0121 & 0.0121 & 0.0240 & 0.0242 & 0.0361 & 0.0362 & 0.0478 & 0.0483 & 0.0598 & 0.0604 \\
283.2. & 0.0156 & 0.0150 & 0.0308 & 0.0301 & 0.0451 & 0.0451 & 0.0602 & 0.0601 & 0.0757 & 0.0752 \\
288.2 & 0.0204 & 0.0206 & 0.0405 & 0.0411 & 0.0619 & 0.0617 & 0.0815 & 0.0822 & 0.102 & 0.103 \\
293.2 & 0.0263 & 0.0262 & 0.0521 & 0.0524 & 0.0776 & 0.0785 & 0.104 & 0.105 & 0.130 & 0.131 \\
\hline
\end{tabular}

\section{Conclusion}

Based on the above discussion and results, we can know that the reaction of potassium ferrate with diethanolamine and triethanolamine both are completed by double-electron transfer. At the same time, we also observe the rate of the rate-determining step of triethanolamine is quicker than that of diethanolamine and the rate constants of the ratedetermining step of triethanolamine at different four temperatures are larger than those of diethanolamine. The effect of $\left[\mathrm{OH}^{-}\right]$and the activation parameters are all in support of the mechanism and consistent with experimental phenomena. 
In the reaction system, we also observe that the activation energy of experiment is very small, but the entropy of activation has a big negative value. So according to the literature ${ }^{19}$, it is reasonable that the reaction rate is not too fast.

\section{Acknowledgment}

This work was supported by funds from the Natural Science Foundation of Hebei Province (No.295066).

\section{References}

1. Duan Y F, Ding Y and Zhang Y Q, Modern Chem Ind., 1998, 3, 17.

2. Wu L P, Henan Chem Ind., 1994, 2, 22.

3. Zhang X Y, Yang C C, Shi Q Z, Guo C F and Zhao L, Chinese J Synthetic Chem., 2006, 14(2),113-117

4. $\quad$ Li X N and Xu N F, Int J Epidemiol Infect Dis., 2006, 33(6), 423-428.

5. Li R Z, Zhang K L and Zhang W, J Shijiazhuang Vocational Technology Institute, 2008, 20(4), 47-49.

6. Yu H L and Hu Z, Science \& Technology in Chemical Industry, 2008, 16(3), 70-74.

7. Waite T D and Gray K A, Stud Environ Sci., 1984, 23, 407-420.

8. Xia Q Y, Fang Z, Wu D L and Chen X, Chemical Industry and Engineering Progress, 2005, 4(3), 245-249.

9. Read J F, Boucher K D and Mehlman S A and Watson K J, Inorg Chim Acta, 1998, 267, 159-163.

10. Murshed M, Rockstraw D A and Hanson A T, Environ Pollut., 2003, 125, 245-253.

11. Virender K S, John T B and Vishwas N J, Environ Sci., 1998, 33(4), 635.

12. Stuart L, Wang B H and Susanta G, Science, 1999, 285(3), 1039-1042.

13. James C, Impact Health Eff., 1985, 1285.

14. James D C, Paul B K and Alfred T E, Environmental Science \& Technology, 1981, 15(2), 184-187.

15. Kelter P B and Carr J D, Anal Chem.,1979, 51, 1828.

16. Dong X W, Detection of all kinds of Ions in the Chemical Method; Beijing Normal University Press: Beijing, 1984, 94.

17. Shan J H, Qian J, Gao M Z, Shen S G and Sun H W, Turk J Chem., 2004, 28, 9-15.

18. Shan J H and Liu T Y, Acta Chim Sinica, 1994, 52, 1140.

19. Fu X C, Shen W X and Yao T Y, Physical Chemistry; Higher Education Press: Beijing, 1990, 812 


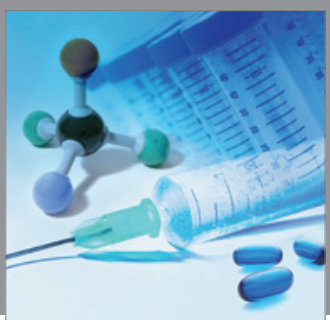

International Journal of

Medicinal Chemistry

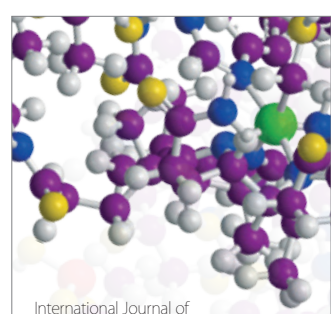

Carbohydrate Chemistry

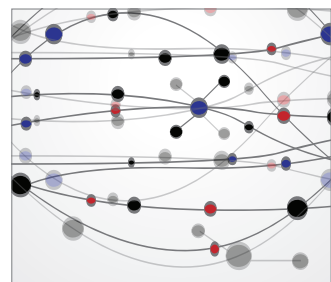

The Scientific World Journal
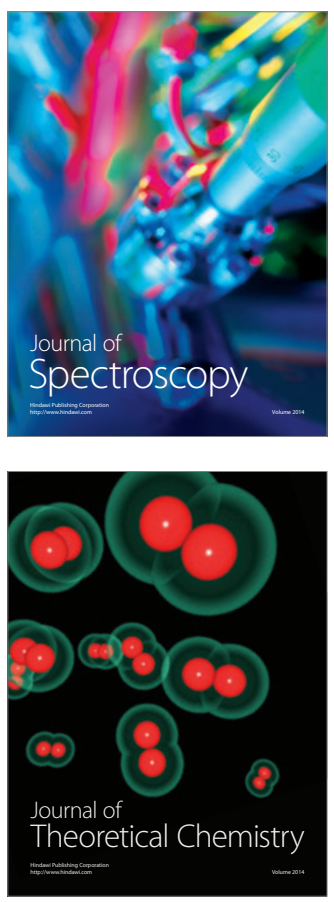
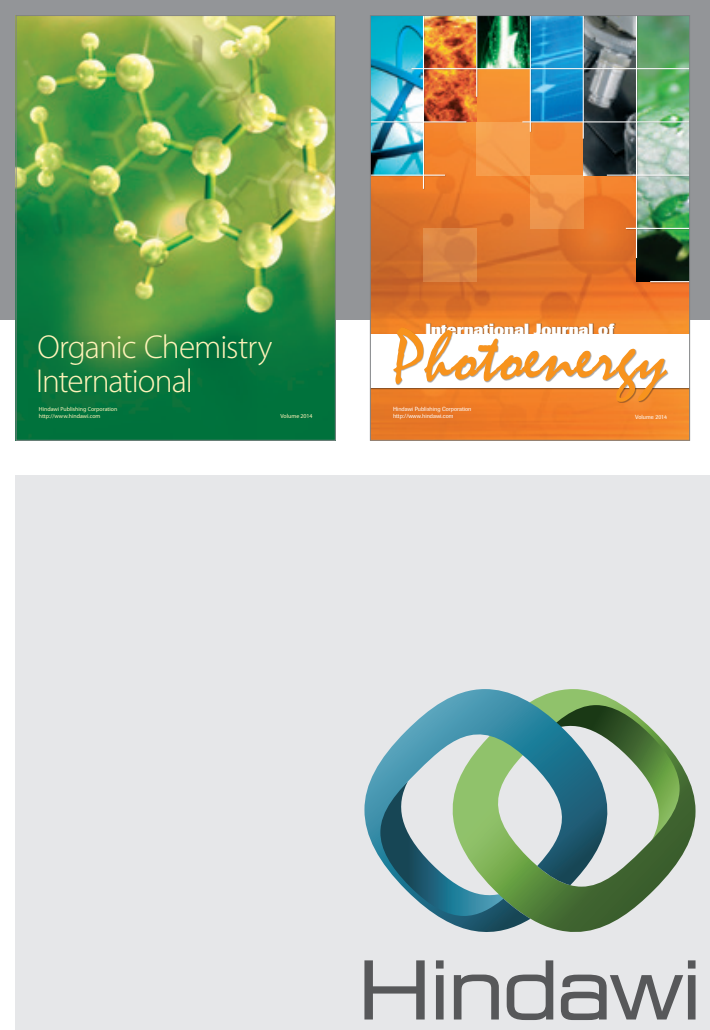

Submit your manuscripts at

http://www.hindawi.com
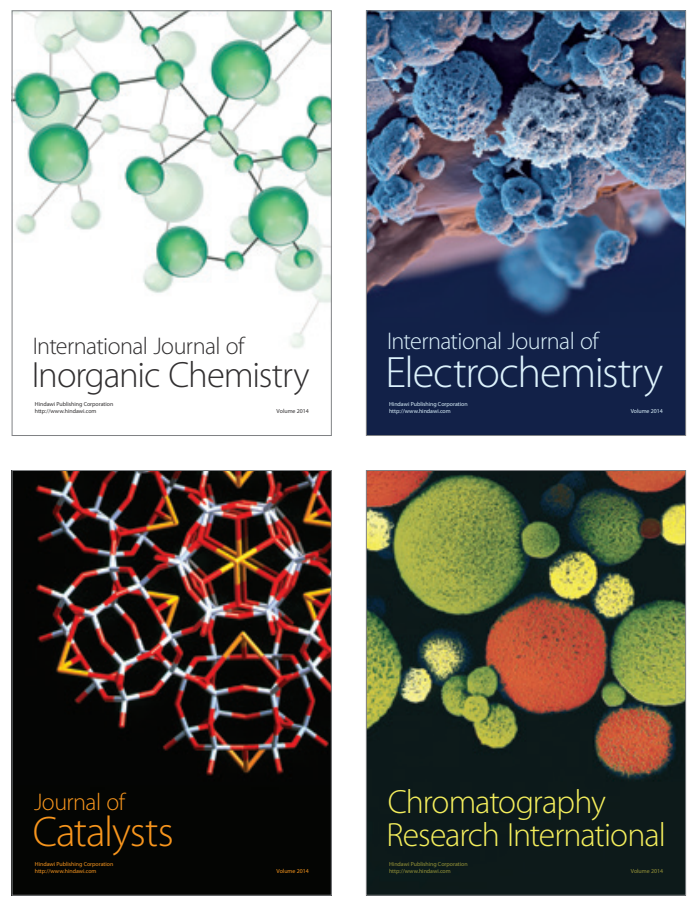
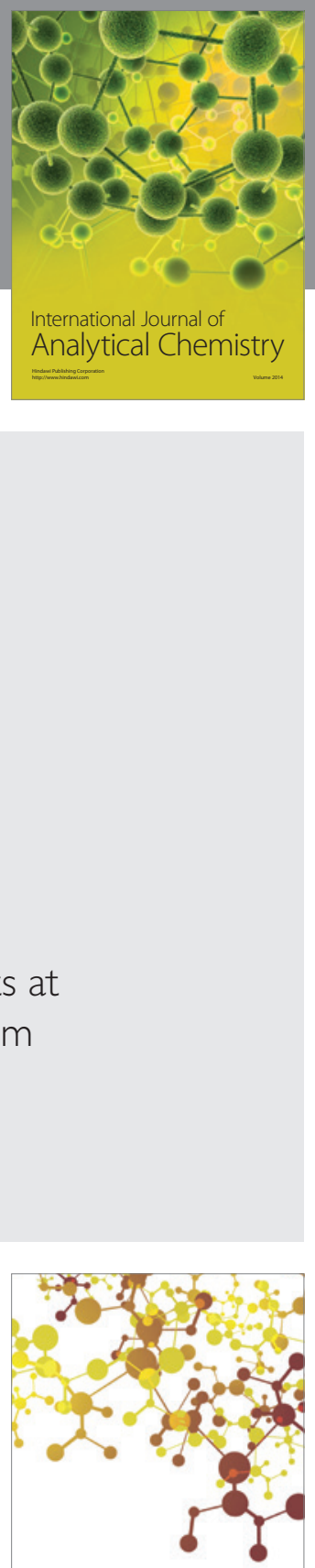

Journal of

Applied Chemistry
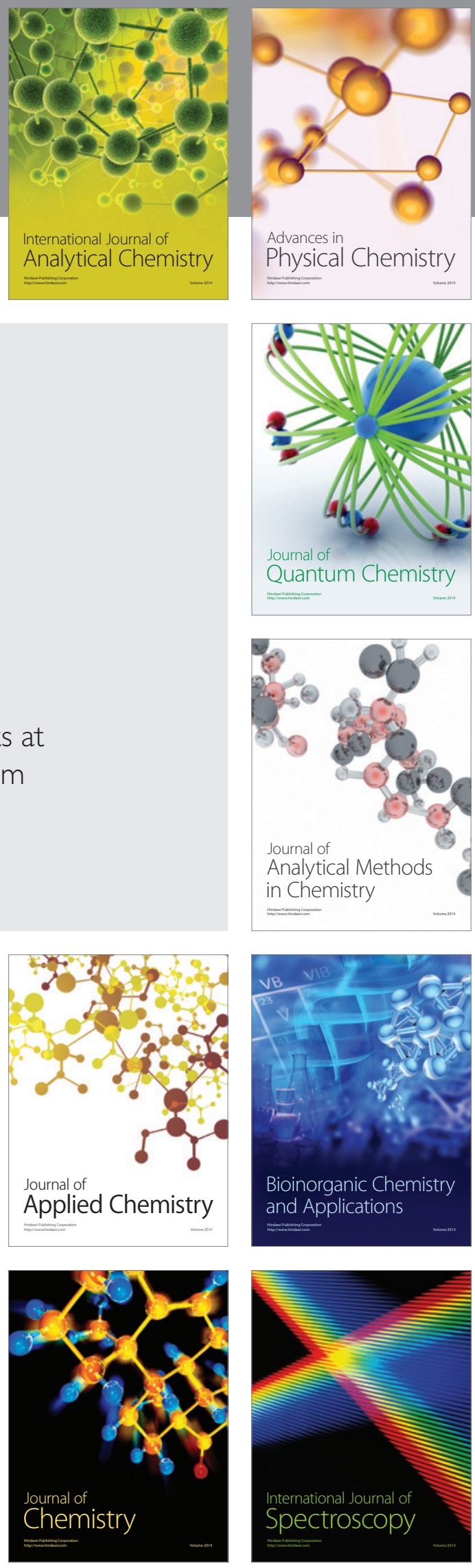